\title{
In Vitro assessment of the nutritive value of expanded soybean meal for dairy cattle
}

\author{
Eman A Elwakeel ${ }^{1}$, Evan C Titgemeyer ${ }^{2 *}$, Zongjia J Cheng ${ }^{3}$, Abdelaziz M Nour ${ }^{1}$ and Mohamed EA Nasser ${ }^{1}$
}

\begin{abstract}
Little information is available about the nutritive value of expanded soybean meal, which is produced by expansion of soybeans prior to solvent extraction of the oil. During processing, expanded soybean meal is subjected to additional heat, which might increase the concentration of ruminally undegraded protein. Processing of soybeans with heat during oil extraction could affect lysine availability by increasing ruminally undegraded protein or by impairing intestinal digestion. Our objective was to compare solvent and expanded soybeans with regard to chemical composition and nutritive value for dairy cattle. Samples of expanded soybean meal $(n=14)$ and solventextracted soybean meal $(n=5)$ were obtained from People's Republic of China to study effects of the expansion process on nutritive value for dairy cattle. Solvent-extracted soybean meal $(n=2)$ and mechanically extracted (heated) soybean meal $(n=2)$ from the United States served as references for comparison. Samples were analyzed for crude fat, long-chain fatty acids, crude protein, amino acids, chemically available lysine, in situ ruminal protein degradation, and in vitro intestinal digestibility. No differences were found between solvent-extracted soybean meals from China and expanded soybean meals from China for crude fat, crude protein, amino acids, or chemically available lysine. In situ disappearance of nitrogen, ruminally undegraded protein content, and in vitro intestinal digestion of the ruminally undegraded protein were generally similar between solvent-extracted soybean meals made in China and expanded soybean meals made in China; variation among soybean meals was small. Results indicate that the additional heat from the expansion process was not great enough to affect the nutritive value of soybean meal protein for ruminants. Although expansion may improve the oil extraction process, the impact on the resulting soybean meal is minimal and does not require consideration when formulating ruminant diets.
\end{abstract}

Keywords: Digestibility, Escape, Lysine, Protein, Rumen

\section{Introduction}

Soybean meal (SBM), a good source of lysine, is widely used as a protein supplement for ruminants [1]. Due to extensive ruminal degradation of protein in SBM, research has focused on treating SBM to increase the ruminally undegraded protein (RUP) content [2].

During solvent extraction of soybeans, the whole soybean is cracked and heated to approximately 60 to $74^{\circ} \mathrm{C}$, then flaked and exposed to hexane solvent to extract the oil $[3,4]$. After the hexane is volatilized, SBM is heated to destroy anti-trypsin factors. For production of expanded SBM, the soybeans are heated by friction during passage through the expander; steam injection may also be

\footnotetext{
* Correspondence: etitgeme@ksu.edu

${ }^{2}$ Department of Animal Sciences and Industry, Kansas State University, Manhattan, KS 66506, USA

Full list of author information is available at the end of the article
}

employed. Upon exit through the expander die at temperatures typically near $120^{\circ} \mathrm{C}$, the sudden drop in pressure expands the product, which destroys cell structure and improves oil extraction and lecithin recovery while reducing the amount of solvent needed [5,6]. After cooling, the expanded product is extracted with hexane, which is similar to solvent extraction of soybeans [5].

The production of expanded SBM is increasingly popular in People's Republic of China, and this has led to a need for information related to its nutritive value, particularly for dairy cattle that could benefit from products with greater concentrations of RUP. Because expanded SBM is subjected to additional heat, it was expected to have greater RUP than solvent-extracted SBM. Processing of soybeans with heat during oil extraction could increase the availability of lysine by increasing RUP or could decrease lysine availability by impairing intestinal

\section{Biomed Central}


digestion. No research is available on the effect of expanded SBM processing on ruminal protein degradability. Douglas and Parsons [7] evaluated the nutritive value of expanded SBM for poultry by measuring its amino acid (AA) content and the protein solubility and also studied the effect of feeding expanded SBM to broiler chicks. They found that the nutritive value of the expanded SBM was similar to standard solvent-extracted SBM.

Our objective was to compare solvent and expanded SBM with regard to chemical composition, chemical lysine availability, in situ ruminal protein degradability, and intestinal protein digestibility of SBM.

\section{Materials and methods}

Procedures for these experiments were approved by the Kansas State University Institutional Animal Care and Use Committee.

\section{Sources of SBM samples}

Twenty-one samples of SBM were obtained from People's Republic of China to study effects of the expansion process on nutritive value for dairy cattle. Among the 21 SBM samples, 14 were expanded SBM (C-eSBM), five were typical solvent-extracted SBM (C-sSBM), and two were expanded full-fat soybeans (C-ff-eSB). The samples were produced at different oil-extraction facilities located throughout China. Specific processing methods were not available for individual samples, and the sources of soybeans were also unknown. Four SBM samples were obtained from the United States to serve as references for methodological validation, and these included two solvent-extracted SBM (US-sSBM) and two mechanically extracted (heated) SBM (US-meSBM).

\section{Chemical composition of SBM}

All SBM samples were analyzed for dry matter $\left(105^{\circ} \mathrm{C}\right.$ in a forced oven for $24 \mathrm{~h})$, ash $\left(450^{\circ} \mathrm{C}\right.$ in ash oven for $16 \mathrm{~h}$ ), crude fat (method number 920.39) [8], crude protein $(\mathrm{N} \times$ 6.25; Kjeldahl procedure), long-chain fatty acids, and AA. Fatty acids were measured by gas chromatography analysis of fatty acid methyl esters [9] using a capillary column $(100 \mathrm{~m} \times 0.25 \mathrm{~mm} \times 0.20 \mu \mathrm{m}$ film) of Supelco SP-2560 (Sigma-Aldrich, St. Louis, MO) with a helium gas flow rate of $1 \mathrm{~mL} / \mathrm{min}$. Amino acids were measured by cationexchange HPLC with $o$-phthalaldehyde post-column derivatization following hydrolysis in $6 \mathrm{~mol} / \mathrm{L} \mathrm{HCl}$ for $24 \mathrm{~h}$ at $105^{\circ} \mathrm{C}$.

\section{Lysine chemical availability}

Available lysine was measured as lysine residues that reacted with 1-fluro-2,4-dinitrobenzene (FDNB) as described by Carpenter [10]. In brief, samples were mixed with $8 \% \mathrm{NaHCO}_{3}$ and reacted with FDNB solution (12 $\mathrm{mL}$ FDNB dissolved in $450 \mathrm{~mL}$ ethanol) for $2 \mathrm{~h}$ at $20^{\circ} \mathrm{C}$ to yield dinitrophenyl-lysine resides from lysine residues with reactive amino groups. Following evaporation of ethanol, $\mathrm{HCl}$ was added to yield a final concentration of $6 \mathrm{~mol} / \mathrm{L}$ and samples were hydrolyzed $105^{\circ} \mathrm{C}$ for $16 \mathrm{~h}$. A portion of each filtered sample was extracted 3 times with diethyl ether to remove interfering compounds and brought to volume with $1 \mathrm{~mol} / \mathrm{L} \mathrm{HCl}$. For blanks, another portion of the filtrate was extracted once with diethyl ether, reacted with methoxycarbonyl chloride to yield an ether-soluble compound from lysine, then acidified with $\mathrm{HCl}$ and extracted 3 times with diethyl ether before being brought to volume with water. Absorbance was measured with a plate reader (PowerWave XS; BioTek, Winooski, VT) at $435 \mathrm{~nm}$. Standards were dinitrophenyl-lysine, and correction for incomplete recovery of dinitrophenyl-lysine was as described by Awawdeh et al. [11].

\section{In situ protein degradability of SBM}

All SBM samples were ground to pass through a 2-mm screen (Wiley Mill; Arthur H. Thomas Co., Philadelphia, $\mathrm{PA})$, and 2-g samples were weighed into Dacron bags (5 $\mathrm{cm} \times 10 \mathrm{~cm} ; 53 \pm 10 \mu \mathrm{m}$ pore size; Ankom Technology, Macedon, NY) to provide a weight/surface ratio of $20 \mathrm{mg} /$ $\mathrm{cm}^{2}$. Bags were heat-sealed and placed in 24 weighted mesh bags ( $36 \mathrm{~cm} \times 42 \mathrm{~cm} ; 26$ Dacron bags/mesh bag), with each mesh bag representing a single fermentation time point $(0,4,8,16,24$, or $48 \mathrm{~h})$. Blank Dacron bags were included for each time point. Bags were presoaked in cold tap water for 15 min before placing all of them (except $0 \mathrm{~h}$ ) in the ventral sacs of the rumen of four ruminally cannulated lactating Holstein cows fed a typical dairy diet (Table 1), then each of the six mesh bags per cow was removed at the determined time point. After they were removed from the rumen, bags were placed immediately in cold tap water, coarsely rinsed for about $15 \mathrm{~min}$, and transferred to the laboratory, where they were washed with a top-loading washing machine (Kenmore Ultra Fabric Care; Sears, Roebuck and Co., Chicago, IL) using cold water for five cycles [12] with $1 \mathrm{~min}$ of agitation and 2min spins [13]. The bags were dried at $55^{\circ} \mathrm{C}$ for $24 \mathrm{~h}$, then air-equilibrated overnight. The nitrogen $(\mathrm{N})$ content of each bag plus residues was determined using the Kjeldahl method.

The undegradability of protein in situ was modeled for each SBM source for each of the four cows separately using the NLIN procedure of SAS (SAS Inst. Inc., Cary, $\mathrm{NC})$ with a model of: Residual $\mathrm{N}=\mathrm{C}+\left(\mathrm{B} \times \mathrm{e}^{-(\mathrm{Kd} \times \mathrm{t})}\right)$, where $\mathrm{C}=$ fraction completely resistant to degradation, $\mathrm{B}=$ potentially degradable fraction, $\mathrm{Kd}=$ fractional rate of disappearance of $B$, and $t=$ time. Because analysis of most SBM samples within most of the cows yielded 
Table 1 Composition of diet fed to cows used for in situ fermentations

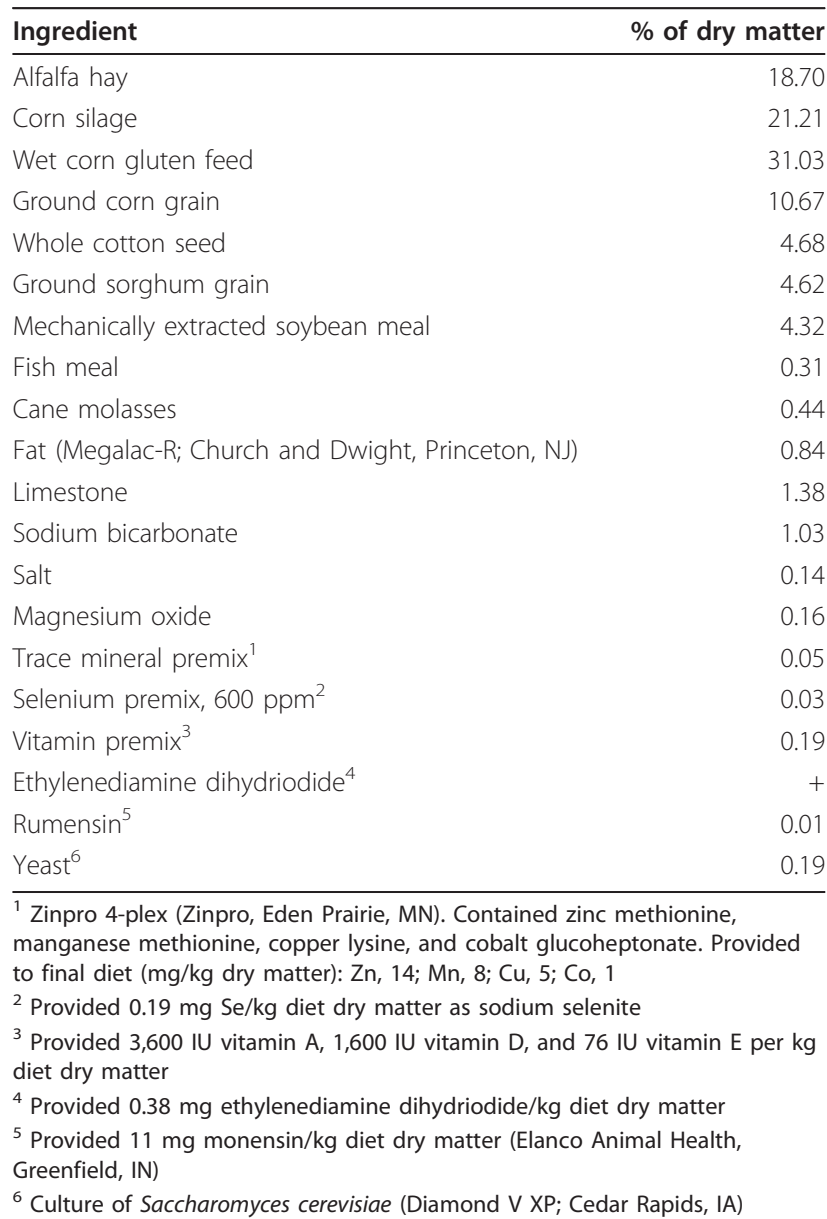

estimates of $\mathrm{C}=0$, the model was modified to: Residual $\mathrm{N}=\mathrm{B} \times \mathrm{e}^{-(\mathrm{Kd} \times \mathrm{t})}$. The RUP was calculated as: RUP $=\mathrm{B}$ $\times(\mathrm{Kp} /(\mathrm{Kp}+\mathrm{Kd}))$, where $\mathrm{Kp}$ were assumed passage rates of $0.04,0.06$, or $0.08 / \mathrm{h}$.

Intestinal digestibility of ruminally undegradable protein (three-step procedure)

Intestinal protein digestibility was determined using the three-step in vitro/enzymatic procedure of Calsamiglia and Stern [14]. Dacron bags containing SBM samples were prepared, incubated in situ for $16 \mathrm{~h}$, and processed as described above. Each sample was incubated in 20 Dacron bags with 5 bags from each SBM sample being incubated in each of 4 cows. Residuals were removed from the bags by cutting off the top of the bags and removing residues by hand. Residues of SBM were composited by cow (5 bags for each SBM sample) and ground using a mortar and pestle. The $\mathrm{N}$ content of the residues was determined using the Kjeldahl method, and these values were used to determine the sample size for measuring intestinal protein digestibility as described by
Calsamiglia and Stern [14]. In brief, samples (15 mg N) were incubated in $10 \mathrm{~mL}$ of pepsin (P-7012, Sigma, St. Louis, MO, USA) solution (1 g/L adjusted to $\mathrm{pH} 1.9$ with $0.1 \mathrm{~mol} / \mathrm{L} \mathrm{HCl}$ ) at $38^{\circ} \mathrm{C}$ for $1 \mathrm{~h}$. Then, $0.5 \mathrm{~mL}$ of 1 $\mathrm{mol} / \mathrm{L} \mathrm{NaOH}$ was added, followed by addition of $13.5 \mathrm{~mL}$ of pancreatin (P-7545, Sigma) solution (3 g/L pancreatin and $50 \mathrm{mg} / \mathrm{L}$ thymol in $\mathrm{KH}_{2} \mathrm{PO}_{4}$ buffer solution adjusted to $\mathrm{pH} 7.8$ ) and incubation at $38^{\circ} \mathrm{C}$ for $24 \mathrm{~h}$. Then, $3 \mathrm{~mL}$ of trichloroacetic acid (100\% wt/vol) was added to stop the enzymatic reaction and precipitate undigested protein. Following centrifugation at $10,000 \times \mathrm{g}$ for $15 \mathrm{~min}$, supernatants were analyzed for $\mathrm{N}$ by the Kjeldahl procedure.

\section{Statistical analyses}

The fraction of $\mathrm{N}$ remaining at each time point was analyzed statistically as a complete block design using the Mixed procedure of SAS (SAS Inst., Inc., Cary, NC). The model contained the effect of cow (blocking factor), time, $\mathrm{SBM}$ classification, and the SBM $\times$ time interaction. Observations for B pool size, Kd, RUP, intestinal digestibility, and total $\mathrm{N}$ availability were analyzed statistically with the Mixed procedure of SAS for a complete block design, with cow serving as the blocking factor. Chemical compositions were analyzed as for a completely randomized design with SBM classification included in the model. Means were separated using pair-wise $t$-tests when the $F$-test was significant $(P<0.05)$.

\section{Results}

\section{Chemical composition of SBM}

Nutrient compositions of SBM samples obtained from China and the United States are presented in Table 2. Organic matter content was greatest for the C-ff-SB and least for US-sSBM $(P<0.05)$. Crude fat differed $(P<0.01)$ among SBM products; C-ff-SB had the highest value (189 $\mathrm{g} / \mathrm{kg}$ ) followed by US-meSBM $(65 \mathrm{~g} / \mathrm{kg})$, but no difference was measured between C-sSBM and C-eSBM for their crude fat content or their long-chain fatty acid profile. The C-ff-SB and US-meSBM contained a lower proportion of long-chain fatty acids as C16:0 and a higher proportion as C18:1 compared with other SBM products $(P<0.01)$.

The C-ff-SB contained less $(P<0.01) \mathrm{CP}$ and AA than the other products. C-sSBM and C-eSBM did not differ in content of $\mathrm{CP}$ or AA.

\section{Lysine chemical availability (FDNB-procedure)}

C-eSBM and C-sSBM did not differ when chemically available lysine was expressed as a proportion of dry matter or as a proportion of total lysine (Table 2). Although lysine availability as a proportion of dry matter was greater for US-sSBM than for US-meSBM, they had similar lysine availability when expressed as proportion of total lysine; thus, the greater availability of lysine 
Table 2 Composition of soybean meal (SBM) samples from China and the United States

\begin{tabular}{|c|c|c|c|c|c|c|}
\hline \multirow[b]{2}{*}{ Item $^{1}$} & \multicolumn{3}{|c|}{ SBM made in China } & \multicolumn{3}{|c|}{ United States SBM } \\
\hline & C-sSBM & C-eSBM & C-ff-eSB & US-sSBM & US-meSBM & SEM $^{2}$ \\
\hline n & 5 & 14 & 2 & 2 & 2 & \\
\hline Organic matter & $930^{b}$ & $929^{b}$ & $943^{\mathrm{a}}$ & $921^{c}$ & $932^{\mathrm{b}}$ & 0.60 \\
\hline Crude fat & $15^{c}$ & $9^{c}$ & $189^{a}$ & $9^{c}$ & $65^{\mathrm{b}}$ & 2.6 \\
\hline Total fatty acids & $16^{\mathrm{c}}$ & $14^{\mathrm{c}}$ & $115^{\mathrm{a}}$ & $14^{\mathrm{c}}$ & $41^{\mathrm{b}}$ & 1.1 \\
\hline C16:0, g/kg FA & $175^{\mathrm{a}}$ & $177^{a}$ & $121^{\mathrm{b}}$ & $172^{a}$ & $125^{\mathrm{b}}$ & 3.7 \\
\hline C18:0, g/kg FA & 45 & 45 & 46 & 44 & 45 & 0.8 \\
\hline C18:1, g/kg FA & $118^{\mathrm{b}}$ & $114^{\mathrm{b}}$ & $187^{\mathrm{a}}$ & $107^{\mathrm{b}}$ & $166^{\mathrm{a}}$ & 5.0 \\
\hline C18:2, g/kg FA & 524 & 526 & 523 & 541 & 530 & 2.4 \\
\hline C18:3, g/kg FA & 97 & 94 & 90 & 95 & 101 & 4.1 \\
\hline $\mathrm{CP}$ & $482^{\mathrm{ab}}$ & $490^{a}$ & $387^{c}$ & $503^{a}$ & $450^{b}$ & 5.2 \\
\hline \multicolumn{7}{|l|}{ Amino acids } \\
\hline Aspartic acid & $53.6^{\mathrm{ab}}$ & $54.4^{\mathrm{a}}$ & $44.5^{c}$ & $54.3^{\mathrm{ab}}$ & $49.5^{b c}$ & 0.77 \\
\hline Threonine & $19.8^{\mathrm{ab}}$ & $20.2^{\mathrm{a}}$ & $16.2^{c}$ & $20.8^{a}$ & $18.7^{b}$ & 0.22 \\
\hline Serine & $26.1^{a}$ & $26.6^{a}$ & $21.4^{c}$ & $27.3^{\mathrm{a}}$ & $24.0^{\mathrm{b}}$ & 0.27 \\
\hline Glutamic acid & $86.8^{\mathrm{a}}$ & $89.1^{\mathrm{a}}$ & $71.3^{\mathrm{b}}$ & $91.6^{\mathrm{a}}$ & $79.2^{\mathrm{b}}$ & 1.10 \\
\hline Glycine & $21.7^{\mathrm{ab}}$ & $22.1^{\mathrm{a}}$ & $17.7^{c}$ & $22.9^{\mathrm{a}}$ & $20.2^{\mathrm{b}}$ & 0.24 \\
\hline Alanine & $21.0^{\mathrm{ab}}$ & $21.5^{\mathrm{a}}$ & $17.2^{c}$ & $21.9^{a}$ & $19.8^{\mathrm{b}}$ & 0.24 \\
\hline Valine & $21.3^{\mathrm{a}}$ & $21.9^{\mathrm{a}}$ & $17.4^{b}$ & $22.1^{\mathrm{a}}$ & $20.2^{\mathrm{a}}$ & 0.30 \\
\hline Methionine & $3.9^{\mathrm{ab}}$ & $4.1^{\mathrm{a}}$ & $3.6^{b}$ & $4.0^{\mathrm{ab}}$ & $3.6^{b}$ & 0.06 \\
\hline Isoleucine & $23.9^{\mathrm{ab}}$ & $24.5^{\mathrm{a}}$ & $19.8^{c}$ & $24.9^{\mathrm{a}}$ & $22.4^{\mathrm{b}}$ & 0.30 \\
\hline Leucine & $36.6^{\mathrm{ab}}$ & $37.5^{\mathrm{a}}$ & $30.2^{c}$ & $38.9^{\mathrm{a}}$ & $34.5^{b}$ & 0.43 \\
\hline Tyrosine & $15.2^{\mathrm{a}}$ & $15.6^{\mathrm{a}}$ & $13.3^{b}$ & $16.1^{\mathrm{a}}$ & $14.6^{\mathrm{ab}}$ & 0.22 \\
\hline Phenylalanine & $25.4^{\mathrm{ab}}$ & $25.9^{\mathrm{a}}$ & $21.0^{c}$ & $26.2^{\mathrm{a}}$ & $23.4^{b c}$ & 0.34 \\
\hline Histidine & $11.6^{\mathrm{a}}$ & $11.9^{\mathrm{a}}$ & $9.9^{b}$ & $11.7^{\mathrm{a}}$ & $11.2^{\mathrm{a}}$ & 0.15 \\
\hline Lysine & $33.8^{\mathrm{ab}}$ & $34.1^{\mathrm{ab}}$ & $27.7^{c}$ & $37.6^{a}$ & $31.8^{\mathrm{bc}}$ & 0.60 \\
\hline Arginine & $32.6^{\mathrm{ab}}$ & $32.9^{\mathrm{a}}$ & $27.9^{c}$ & $33.2^{\mathrm{a}}$ & $30.3^{b c}$ & 0.36 \\
\hline Total amino acids & $433^{\mathrm{ab}}$ & $442^{\mathrm{a}}$ & $359^{c}$ & $453^{\mathrm{a}}$ & $404^{b}$ & 4.8 \\
\hline Amino acids, g/kg CP & 899 & 903 & 928 & 901 & 897 & 4.8 \\
\hline Available lysine & $28.2^{\mathrm{ab}}$ & $28.1^{\mathrm{ab}}$ & $23.8^{c}$ & $29.8^{\mathrm{a}}$ & $26.3^{\mathrm{bc}}$ & 0.38 \\
\hline Available lysine, $\mathrm{g} / \mathrm{kg}$ total lysine & 840 & 825 & 863 & 794 & 830 & 15 \\
\hline
\end{tabular}

Within a row, products not sharing a common superscript are significantly different $(P<0.05)$

C-sSBM, solvent SBM made in China; C-eSBM, expanded SBM made in China; C-ff-eSB, full-fat expanded soybeans made in China; US-sSBM, United States solvent SBM; US-meSBM, United States mechanically extracted SBM; FA, fatty acids; CP, crude protein

${ }^{1}$ All values reported as $\mathrm{g} / \mathrm{kg}$ of dry matter, except where indicated otherwise

2 Standard error of the mean for $n=14$. To obtain SEM for $n=5$, multiply by 1.67 ; to obtain SEM for $n=2$ multiply by 2.65

for US-sSBM than for US-meSBM was due to the higher total lysine content.

\section{In situ protein degradability of SBM}

As expected, the proportion of $\mathrm{N}$ from the SBM remaining in situ decreased over time for all SBM products, with only a small amount of $\mathrm{N}$ remaining at 48 h except for C-ff-SB and US-meSBM (Table 3). No differences occurred in proportions of $\mathrm{N}$ remaining between C-sSBM and C-eSBM at $0,4,8,24$, or $48 \mathrm{~h}$. The C-eSBM had significantly more $\mathrm{N}$ remaining at 16 $\mathrm{h}$ when compared with C-sSBM; this difference was not large enough to lead to differences in the predicted rates of in situ degradation or in the predicted RUP (Table 3).

\section{In situ kinetics of ruminal protein degradability of SBM}

The insoluble $\mathrm{N}$ fraction (B pool) was similar among $\mathrm{C}$ eSBM, C-sSBM, and US-sSBM (Table 3); however, the insoluble $\mathrm{N}$ was less for C-ff-eSB and US-meSBM than for the other products. The model-calculated values of insoluble $\mathrm{N}$ were generally comparable to the measured residual $\mathrm{N}$ at $0 \mathrm{~h}$ (Table 3), suggesting that the model appropriately predicted the soluble $\mathrm{N}$ pool. No differences were measured between C-eSBM and C-sSBM for Kd (Table 3). Also, no difference was found between C-sSBM, USsSBM, and C-ff-eSB for Kd. The US-meSBM had the slowest $(P<0.01)$ rate of degradation among SBM sources.

No differences were found between C-eSBM and CsSBM for their predicted RUP at the three passage rates (Table 3). 
Table 3 In situ protein degradability and intestinal availability of $\mathbf{N}$ from soybean meals (SBM) from China and the United States

\begin{tabular}{|c|c|c|c|c|c|c|}
\hline \multirow[b]{2}{*}{ Item } & \multicolumn{3}{|c|}{ SBM made in China } & \multicolumn{3}{|c|}{ United States SBM } \\
\hline & C-sSBM & C-eSBM & C-ff-eSB & US-sSBM & US-meSBM & SEM $^{1}$ \\
\hline$n$ & 5 & 14 & 2 & 2 & 2 & \\
\hline \multicolumn{7}{|l|}{$\mathrm{N}$ remaining in situ, $\mathrm{g} / \mathrm{g}$} \\
\hline $\mathrm{Oh}$ & $0.909^{a}$ & $0.897^{\mathrm{a}}$ & $0.768^{b}$ & $0.878^{\mathrm{ab}}$ & $0.808^{b}$ & 0.016 \\
\hline $4 \mathrm{~h}$ & 0.691 & 0.710 & 0.630 & 0.669 & 0.691 & \\
\hline $8 \mathrm{~h}$ & $0.511^{\mathrm{ab}}$ & $0.516^{\mathrm{ab}}$ & $0.485^{b}$ & $0.439^{b}$ & $0.603^{a}$ & \\
\hline $16 \mathrm{~h}$ & $0.219^{c}$ & $0.293^{\mathrm{bd}}$ & $0.300^{\mathrm{bc}}$ & $0.218^{\mathrm{cd}}$ & $0.444^{\mathrm{a}}$ & \\
\hline $24 \mathrm{~h}$ & $0.112^{c}$ & $0.134^{c}$ & $0.223^{b}$ & $0.056^{c}$ & $0.356^{\mathrm{a}}$ & \\
\hline $48 \mathrm{~h}$ & $0.014^{b}$ & $0.014^{b}$ & $0.072^{\mathrm{ab}}$ & $0.006^{\mathrm{ab}}$ & $0.113^{\mathrm{a}}$ & \\
\hline \multicolumn{7}{|l|}{ In situ $N$ kinetics } \\
\hline B pool, g/g & $0.934^{\mathrm{a}}$ & $0.921^{a}$ & $0.785^{c}$ & $0.906^{\mathrm{ab}}$ & $0.811^{b c}$ & 0.013 \\
\hline $\mathrm{Kd}, \mathrm{h}^{-1}$ & $0.0857^{\mathrm{a}}$ & $0.0762^{\mathrm{a}}$ & $0.0697^{\mathrm{a}}$ & $0.0942^{a}$ & $0.0386^{\mathrm{b}}$ & 0.0031 \\
\hline \multicolumn{7}{|l|}{$R \cup P, g / g^{2}$} \\
\hline $\mathrm{Kp}=0.04 / \mathrm{h}$ & 0.305 & 0.326 & 0.328 & 0.279 & 0.420 & 0.013 \\
\hline $\mathrm{Kp}=0.06 / \mathrm{h}$ & 0.392 & 0.414 & 0.402 & 0.361 & 0.499 & 0.015 \\
\hline $\mathrm{Kp}=0.08 / \mathrm{h}$ & 0.458 & 0.479 & 0.455 & 0.424 & 0.552 & 0.015 \\
\hline \multicolumn{7}{|l|}{ Three-step procedure ${ }^{3}$} \\
\hline 16-hour RUP, g/g & $0.236^{b}$ & $0.263^{b}$ & $0.315^{\mathrm{ab}}$ & $0.178^{b}$ & $0.434^{a}$ & 0.019 \\
\hline Intestinal digestion, g/g & 0.832 & 0.827 & 0.846 & 0.832 & 0.843 & 0.0033 \\
\hline Total availability, g/g & $0.199^{b}$ & $0.220^{\mathrm{b}}$ & $0.269^{\mathrm{ab}}$ & $0.148^{b}$ & $0.374^{\mathrm{a}}$ & 0.016 \\
\hline
\end{tabular}

Within a row, products not sharing a common superscript are significantly different $(P<0.05)$

C-sSBM, solvent SBM made in China; C-eSBM, expanded SBM made in China; C-ff-eSB, full-fat expanded soybeans made in China; US-sSBM, United States solvent SBM; US-meSBM, United States mechanically extracted SBM; N, nitrogen; B pool, potentially degraded fraction; Kd, degradation rate of B pool; RUP, ruminally undegraded protein; $\mathrm{Kp}$, ruminal passage rate

${ }^{1}$ Standard error of the mean for $n=14$. To obtain SEM for $n=5$, multiply by 1.67 ; to obtain SEM for $n=2$ multiply by 2.65

${ }^{2}$ Calculated as: $\mathrm{B} \times(\mathrm{Kp} /(\mathrm{Kp}+\mathrm{Kd}))$

${ }^{3}$ Calsamiglia and Stern [12]

\section{Intestinal digestibility of RUP (three-step procedure)}

The 16-h RUP concentrations differed $(P<0.05)$ among SBM products (Table 3). The US-meSBM had the highest 16-h RUP and US-sSBM had the least 16-h RUP. No difference was detected between the C-eSBM and C-sSBM for 16-h RUP or among SBM products for intestinal digestion of RUP determined by the 3-step procedure (Table 3).

Total availability of $\mathrm{N}$ calculated by multiplying the 16-h RUP by its intestinal digestibility differed $(P<0.01)$ among SBM products with the same pattern as for 16-h bypass (Table 3).

\section{Discussion}

\section{Chemical composition of SBM}

The lower proportion of long-chain fatty acids as C16:0 and a higher proportion as C18:1 for C-ff-SB and USmeSBM compared with other SBM products likely reflects that the composition of fatty acids in triglycerides differs from that of phospholipids and that more triglycerides remained in the higher fat products.

The lower CP and AA content of C-ff-SB reflects the dilution of these components by the greater amounts of fat. The $\mathrm{CP}$ and AA contents of $\mathrm{C}$-eSBM were close to values for expanded SBM reported by Douglas and Parsons [7]. The CP and AA compositions of US-sSBM were comparable to National Research Council [15] values, and the CP and AA compositions of US-meSBM were comparable to those reported by Borucki Castro et al. [16].

\section{Lysine chemical availability}

In the FDNB assay, unbound lysine residues react with FDNB to yield dinitrophenyl-lysine and are considered nutritionally available, whereas lysine residues in which the $\varepsilon$-amino group is bound will not react with FDNB and are not measured [17]. Faldet et al. [2] studied the effect of heat intensity and duration on lysine availability using the FDNB technique and a rat growth assay, and they reported that lysine availability was reduced with increasing heat intensity and duration. They also reported that the FDNB method provided accurate measures of available lysine when the result was compared with body weight gain of rats.

The expansion of SBM prior to fat extraction had no effect on lysine availability in the set of Chinese samples that we evaluated, indicating that heat during the expansion process was not high enough to cause protein 
damage. The coefficient of variation (standard deviation/ mean) for available lysine among C-eSBM samples was small (0.05), indicating that there was not large variation among sources.

\section{In situ kinetics of ruminal protein degradability of SBM}

The process of denaturation and cross-link formation during heating reduces protein solubility and makes protein less available for rumen degradation by rumen micro-organisms [18]. The reduction of ruminal protein degradability by heating has been reported by many researchers [19-22]. Although we had expected that the additional heat from the expansion process might reduce ruminal protein degradability, our results indicate that the C-eSBM samples did not undergo enough additional heating during the expansion process to affect nutritive value of the protein for ruminants. In general, the temperature used in the expanding process is around $120^{\circ} \mathrm{C}$, and the pressure can be automatically controlled. In contrast, during extrusion processes that impact degradability of soybean proteins, the temperature often reaches $165^{\circ} \mathrm{C}$. Prestløkken [23] demonstrated that expansion of SBM with an outlet temperature of $129^{\circ} \mathrm{C}$ increased the RUP content. The lack of difference between C-eSBM and $\mathrm{C}$-sSBM for ruminal protein degradability might indicate either that temperatures less than $129^{\circ} \mathrm{C}$ were used during the expansion process for C-eSBM or that expansion of soybeans before oil extraction impacts the soybean proteins less than expansion of SBM. Regardless, expansion did not have significant effects on RUP for the samples we evaluated.

The US-meSBM had numerically greater RUP than other products due to slower rates of ruminal degradation of protein; they also had a somewhat larger soluble $\mathrm{N}$ pool (1-B pool) than the other SBM, which would decrease the predicted RUP. Awawdeh et al. [11] found numerically greater soluble $\mathrm{N}$ in mechanically extracted SBM compared with solvent-extracted SBM. The greater soluble N of US-meSBM could be explained by destruction of some of the polypeptide bonds in SBM proteins as a result of heat; Wolf [24] reported that temperatures greater than $100^{\circ} \mathrm{C}$ could increase protein solubility as a result of destruction of polypeptide bonds. However, the higher RUP for US-meSBM indicates that much of the protein underwent denaturation that reduced ruminal protein degradability by rumen micro-organisms. The estimated RUP of US-sSBM at passage rate of $0.08 / \mathrm{h}$ was similar to the estimated RUP of 0.43 reported by the National Research Council [15].

\section{Intestinal digestibility of RUP (three-step procedure)}

Heat treatment can improve intestinal digestibility because of the destruction of the anti-trypsin factors by heat [25]. Aldrich et al. [26] found that the anti-trypsin activity was reduced linearly with increasing temperature during extrusion of soybeans. Solanas et al. [27] reported that extrusion of SBM increased the intestinal digestibility of the bypass protein; however, excessive heat reduces protein digestibility and causes destruction to essential AA, especially lysine, which is considered the most sensitive AA to heat [28]. Demjanec et al. [20] investigated the effect of heating SBM at $165^{\circ} \mathrm{C}$ for 0 , $75,150,180$, or $210 \mathrm{~min}$ on $\mathrm{N}$ flow to and digestibility in the small intestine of wethers fitted with duodenal and ileal canulas. Intestinal digestion of SBM-N increased with heating times up to $150 \mathrm{~min}$, then declined as heating time was extended; this demonstrates both the beneficial effects of moderate heating and the negative effects of overheating.

The lack of difference among treatments for intestinal digestibility along with the small standard error for intestinal digestion suggests that products were quite similar and that none experienced significant heat damage. Given the lack of treatment difference for intestinal digestion, it is not surprising that the pattern for total $\mathrm{N}$ availability was predominantly dictated by 16-h RUP rather than by intestinal digestion.

\section{Summary}

Our data demonstrated no large differences between CeSBM and C-sSBM in nutrient composition, ruminal protein degradability, or intestinal protein digestibility indicating that heating during the expansion process was not enough to affect the nutritive value of SBM for ruminants. Although the expansion process may improve the oil extraction process, our in vitro data suggest that effects of expansion on the resulting SBM will not require consideration when formulating ruminant diets. If more extensive heating was applied with the goal of altering SBM proteins, then further research may be warranted to evaluate new processes.

\section{Acknowledgements}

Contribution Number 12-028-J from the Kansas Agricultural Experiment Station, Manhattan, Kansas. Financial support from the Kansas Soybean Commission is greatly appreciated.

\section{Author details}

'Department of Animal \& Fish Production, Faculty of Agriculture, Alexandria University, Alexandria 21545, Egypt. ${ }^{2}$ Department of Animal Sciences and Industry, Kansas State University, Manhattan, KS 66506, USA. ${ }^{3}$ American Soybean Association-International Marketing, Beijing, China.

\section{Authors' contributions}

EAE participated in design of the research, carried out the experiment, analyzed data, and drafted the manuscript. ECT designed the research, coordinated the research, conducted statistical analyses, and had primary control of the final content of the manuscript. ZJC participated in design of the research, collected soybean samples from China, and contributed to preparation of the manuscript. AMN and MEAN participated in design of the research and contributed to preparation of the manuscript. All authors read and approved the final manuscript. 


\section{Competing interests}

The authors declare that they have no competing interests.

Received: 28 February 2012 Accepted: 20 March 2012

Published: 20 March 2012

\section{References}

1. Schingoethe DJ: Balancing the amino acids needs of the dairy cow. Anim Feed Sci Technol 1996, 60:153-160.

2. Faldet MA, Satter LD, Broderick GA: Determining optimal heat treatment of soybeans by measuring available lysine chemically and biologically with rats to maximize protein utilization by ruminants. J Nutr 1992, 122:151-160.

3. Blasi DA, Drouillard J, Titgemeyer EC, Paisley SI, Brouk MJ: Soybean hulls, composition and feeding value for beef and dairy cattle. Agric Exp Sta, Kansas State Univ, Manhattan, KS, USA; 2000, Contribution No. 00-79-E.

4. Newkirk R: Soybean: Feed industry guide, 1st edition. Canadian International Grains Institute 2010 [http://cigi.ca/wp-content/uploads/2011/ 12/2010-Soybean-Feed-Industry-Guide.pdf].

5. Lusas EW, Watkins LR: Oilseeds: extrusion for solvent extraction. J Am Oil Chem Soc 1988, 65:1109-1114.

6. Watkins LR, Johnson WH, Doty SC: Oil-seed: Extrusion for solvent extraction. Proceedings of the World Congress on Vegetable Protein Utilization in Human Foods and Animal Feedstuffs American Oil Chemist's Society, Champaign, IL, USA; 1989, 41-46.

7. Douglas MW, Parsons CM: Effect of presolvent extraction processing method on the nutritional value of soybean meal for chicks. J Poultry Sci 2000, 79:1623-1626.

8. AOAC: Official Methods of Analysis. 15 edition. Arlington: Association of Official Analytical Chemists; 1990.

9. Sukhija PS, Palmquist DL: Rapid method for determination of total fatty acid content and composition of feedstuffs and feces. J Agric Food Chem 1988, 36:1202-1206.

10. Carpenter K: The estimation of available lysine in animal-protein foods. Biochem J 1960, 77:604-610.

11. Awawdeh MS, Titgemeyer EC, Drouillard JS, Beyer RS, Shirley JE: Ruminal degradability and lysine bioavailability of soybean meals and effects on performance of dairy cows. J Dairy Sci 2007, 90:4740-4753.

12. Vanzant ES, Cochran RC, Titgemeyer EC: Standardization of in situ techniques for ruminant feedstuff evaluation. J Anim Sci 1998 76:2717-2729.

13. Coblentz WK, Fritz JO, Cochran RC, Rooney WL, Bolsen KK: Protein degradation in response to spontaneous heating in alfalfa hay by in situ and ficin methods. J Dairy Sci 1997, 80:700-713.

14. Calsamiglia S, Stern MD: A three-step in vitro procedure for estimating intestinal digestion of protein in ruminants. J Anim Sci 1995, 73:1459-1465.

15. NRC: Nutrient Requirements of Dairy Cattle. 7 edition. Washington: Natl Acad Sci; 2001.

16. Borucki Castro SI, Phillip LE, Lapierre H, Jardon PW, Berthiaume R: Ruminal degradability and intestinal digestibility of protein and amino acids in treated soybean meal products. J Dairy Sci 2007, 90:810-822.

17. Hurrell RF, Carpenter KJ: The estimation of available lysine in foodstuffs after Maillard reactions. Prog Food Nutr Sci 1981, 5:159-176.

18. Cleale RM IV, Britton RA, Klopfenstein TJ, Bauer ML, Harmon DL, Satterlee LD: Induced non-enzymatic browning of soybean meal. II. Ruminal escape and net portal absorption of soybean protein treated with xylose. J Anim Sci 1987, 65:1319-1326.

19. Waltz DM, Stern MD: Evaluation of various methods for protecting soyabean protein from degradation by rumen bacteria. Anim Feed Sci Technol 1989, 25:111-122.

20. Demjanec B, Merchen NR, Cremin JD Jr, Aldrich CG, Berger LL: Effect of roasting on site and extent of digestion of soybean meal by sheep: I. Digestion of nitrogen and amino acids. J Anim Sci 1995, 73:824-834.

21. Maiga HA, Schingoethe DJ, Henson JE: Ruminal degradation, amino acid composition and intestinal digestibility of the residual components of five protein supplements. J Dairy Sci 1996, 79:1647-1653.

22. McNiven MA, Prestløkken E, Mydland LT, Mitchell AW: Laboratory procedure to determine protein digestibility of heat-treated feedstuffs for dairy cattle. Anim Feed Sci Technol 2002, 96:1-13.
23. Prestløkken E: In situ ruminal degradation and intestinal digestibility of dry matter and protein in expanded feedstuffs. Anim Feed Sci Technol 1999, 77:1-23.

24. Wolf WJ: Purification and properties of the proteins. In Soybeans: Chemistry and Technology. Volume 1. Proteins. Revised Second Printing. Edited by: Smith AK, Circle SJ. Westport: Avi Publ. Co; 1978:93-143.

25. Eweedah N, Gundel J, Mátrai T: Protein degradability, amino acid composition, trypsin inhibitor and urease activity of raw and heattreated fullfat soybean. Arch Anim Nutr 1997, 50:361-367.

26. Aldrich CG, Merchen NR, Parsons CM, Hussein HS, Ingram S, Coldfelter JR: Assessment of postruminal amino acid digestibility of roasted and extruded whole soybeans with precision-fed rooster assay. J Anim Sci 1997, 75:3046-3051.

27. Solanas EM, Castrillo C, Jover M, de Vega A: Effect of extrusion on in situ ruminal protein degradability and in vitro digestibility of undegraded protein from different feedstuffs. J Sci Food Agric 2008, 88:2589-2597.

28. Smith GA, Friedman M: Effect of carbohydrate and heat on the amino acid composition and chemically available lysine content of casein. $J$ Food Sci 1984, 49:817-820.

doi:10.1186/2049-1891-3-10

Cite this article as: Elwakeel et al: In Vitro assessment of the nutritive value of expanded soybean meal for dairy cattle. Journal of Animal Science and Biotechnology 2012 3:10.

\section{Submit your next manuscript to BioMed Central and take full advantage of:}

- Convenient online submission

- Thorough peer review

- No space constraints or color figure charges

- Immediate publication on acceptance

- Inclusion in PubMed, CAS, Scopus and Google Scholar

- Research which is freely available for redistribution 